\title{
A proposed educational vision for caring the disabled in Upper Egypt in the light of some social contemporary variables
}

\section{*Dr/ Abdullah Farghali Ahmed Khamess}

\section{Abstract}

The recognizing of the handicapped participation reality in the sportive activates within sports centers and its obstacles, recognizing the activates implementation reality within sportive centers for training the physical handicapped, the researcher designed a questionnaire form contains 2 principal dimensions the first main dimension aimed to recognize on the active participation reality in the educational activity in the sportive centers of handicapped care the second main dimension aims to discover the extent of achievement and implementation the educational activity in the real world and applied it upon samples from 31 handicapped the researcher used the descriptive method The study had reach the following results :There are insignificance deferential correlations between males and females in the form axes about the reality in the educational activity implementation hence the calculated $(\mathrm{r})$ ranges from (0.01 to1.87) and it's small than its tabular value on (0.05)

Key words: The handicapped / The educational activates

\section{The research introduction}

The disability is not a indignation but it is certainly a bless for the disabled person, since it may be a test to him by God and it may strength his will and persistence in life, it also may be a reason to acquire the people's love and makes him love his disabled colleagues and it also may increase his efficiency and his remaining abilities to make him perform with a level higher than the sound people (11-27).

Both Helmy Ibrahim and Layla Farahat (1998) indicate that the World Health Organization has estimated the number of the disabled around

Assistant professor at the faculty of physical education- Assuit University

Assiut Journal For Sport Science Arts 
the world to be about 530 million persons, including (122) million children live in the third world (1). Medhat Abu Al Naser (2009) indicates that the United Nations estimations to the number of the disabled around the world in 2000 reached about 600 million persons, $(80 \%)$ of them live in the developing countries and they get only( $1 \%$ or $2 \%$ ) from the services of requalification(6,37).

In Egypt, the number of population reached about $(67,688,229)$ million on January 2002 inside and outside Egypt, including $(33.765,00)$ male representing $(51.2 \%)$ of the population and (32.20000.00) female representing (48.4\%). In 2006, the population number reached about (72.613.352) million, accordingly, the number of the disabled increased to reach about (7) million persons $(2,370)$.

The disabled are a large category at the society which represents about (10: 15\%) of the population in Egypt. There are various forms of the disability, including the auditory, the visual, the mental and the physical disability. The rate of the physical disability alone reached about 3\%, since the number of the persons with a physical disability according to the estimations in 2006 was over (15420) person (2- 150).

The look is an urgent need to assess care and rehabilitation programs Educational because the size of the problem of the disabled has increased severely in the world due to several factors, the most important of wars and natural disasters, and in general the numbers of people with disabilities is increasing and confirms the statistics for the disabled According to the statistics of the World Bank estimated the proportion of disability, including nearly $(12 \%)$ of the world's population .but Tgarirmenzmh who and the world Bank for the population for the year 2012 that there are more than one billion people around the world suffer from disabilities.

A caring was given to all categories of disability, in particular the persons with the physical disability who got a large caring during the last few years, whether regarding the scientific or the technological study. This caring and attention may be due to the increasing conviction in the societies that 
the persons with a physical disability are like the other sound persons and they have the right to share the life and development according to their abilities $(19,98)$.

There is semi-consensus on the world level that the largest obstacles that prevent the spread of requalification programs are represented in the rarity of the trainers who work in these programs and the lack of the institutes and the training centers that prepare these categories before and during the service as well as the shortcomings in the current training programs. This in its turn depends on the opportunities and preparation and training and developing the professional abilities and the high practical skills available to the personnel in the qualification programs inside the educational institutions and caring the disabled $(4,10)$. The problems which face the physically handicapped persons are represented in their interaction with the others which causes shame and embarrassment regarding some social situations as well as the instable reactions that are practiced by the others towards them and the negative attitudes of the others towards them. Some studies have indicated that the physically handicapped persons face a lot of problems in their social interactions with the sound persons in comparing to their interactions with their counterparts. However, the physically handicapped persons suffer more from the social bias against them (6, 35). Accordingly, our reality indicates some facts, namely:

- The people's wrong attitudes and their point of view to the disabled that is more than the disability itself.

- The excess piety towards the disabled and the disturbing cruelty as result of the depression and impatience.

- $\quad$ Looking at the disabled as a burden as result of the wrong upbringing which makes him depend on the others.

Since the centers of training for the physically handicapped persons are centers that follow the ministry of youth and concern with providing the activities for the physically handicapped persons and its role as educational institutions for caring the disabled, they must provide the educational activities necessary for achieving the goals of the 
education process in the way that is proper to the different physical disabilities and the trends of the disabled.

Since the current status of the sports centers for training the physically handicapped persons don't meet the requirements of caring this category regarding providing the proper educational activities as the role of these centers is limited to providing some sports activities for limited numbers in certain age, as well as the weakness of the educational activities in these centers, this study attempts to recognize the actual reality of some educational requirements for the physically handicapped persons inside the sports centers for training the physically handicapped persons in Assuit governorate in the light of some social contemporary variables.

\section{The importance of the study}

1- Highlighting some educational activities that are necessary for caring the physically handicapped persons.

2- This study is useful for those who put the plan of the educational activities for the sports centers for training the disabled.

3- The studies conducted on the disabled are few in relation to the researches of the other disabilities.

4- Enriching the Arabic library with such researches that focus on an important category in the society.

\section{The study goals:}

1- Knowing the reality of participation by the physically handicapped persons in the educational centers and its obstacles.

2- Knowing the reality of executing the activities included in the sports centers of training the physically handicapped persons.

3- $\quad$ Trying to put a proposed vision for the educational activities necessary for caring the physically handicapped persons.

\section{The study questions:}

1- What is the reality of participation by the physically handicapped persons in the educational activities at the sports centers and its obstacles?

2- What is the reality of executing the activities included in the sports centers of training the physically handicapped persons?

3- What is the proposed vision for activating the role of the educational activities inside the sports centers of training the physically handicapped persons?

\section{The research procedures}

\section{First: The research methodology:}

The descriptive methodology and the interview were used for supporting and clearing the results got through the questionnaire as a tool for

\section{Assiut Journal For Sport Science Arts}


collecting information and data.

Second: the research society: The research society consists of the disabled persons who participate in the sports centers that follow the ministry of sport and youth in Assuit governorate whose number reached (600) members of the physically handicapped persons at the club of the Christian youth in Assuit.
Third: The society sample:

The research sample was chosen randomly from the disabled members who participate in the different educational activities at the center of caring the disabled in the club of Christian youth in Assuit. The number of the sample individuals reached (20) persons with a physical disability.

Table (1)

description of the research sample chosen from the physically handicapped persons

\begin{tabular}{l|c|c|c}
\hline \hline The research sample & Males & Females & The total \\
\hline \hline Number & 9 & 11 & 20 \\
\hline \hline
\end{tabular}

Fourth: The tools of collecting data:

1- The researcher has shown the axis in its initial image to a group of experts in the faculties of physical education with the aim of reaching the main axes ( 8 axes) for investigating the annex number (2), then, the researcher has designed a questionnaire form which included two main dimensions, the first dimension aims to recognize the reality of the active participation in the educational activities practiced inside the sports centers for caring the disabled, this axis included eight subaxes. The second dimension aims to explore and reveal the extent of achieving and executing the educational activities in the real world and it included seven sub-axes.

Table (2)

shows the main axes of the questionnaire about the reality of executing the educational activities and their participation

The axes that relate to the reality of executing and the active participation of the physically handicapped persons in the educational activities inside the sports centers 


\begin{tabular}{|c|c|c|c|c|c|c|c|}
\hline $\begin{array}{l}\text { The } \\
\text { first } \\
\text { axis }\end{array}$ & $\begin{array}{l}\text { The } \\
\text { religious } \\
\text { activity }\end{array}$ & $\begin{array}{l}\text { The } \\
\text { third } \\
\text { axis }\end{array}$ & $\begin{array}{l}\text { The } \\
\text { artistic } \\
\text { activity }\end{array}$ & $\begin{array}{l}\text { The } \\
\text { fifth } \\
\text { axis }\end{array}$ & $\begin{array}{l}\text { The } \\
\text { social } \\
\text { activity }\end{array}$ & $\begin{array}{l}\text { The } \\
\text { seventh } \\
\text { axis }\end{array}$ & $\begin{array}{l}\text { The } \\
\text { psychological } \\
\text { qualification }\end{array}$ \\
\hline $\begin{array}{l}\text { The } \\
\text { second } \\
\text { axis }\end{array}$ & $\begin{array}{l}\text { The } \\
\text { cultural } \\
\text { activity }\end{array}$ & $\begin{array}{l}\text { The } \\
\text { fourth } \\
\text { axis }\end{array}$ & $\begin{array}{l}\text { The } \\
\text { sports } \\
\text { activity }\end{array}$ & $\begin{array}{l}\text { The } \\
\text { sixth } \\
\text { axis }\end{array}$ & $\begin{array}{l}\text { The } \\
\text { political } \\
\text { activity }\end{array}$ & $\begin{array}{l}\text { The } \\
\text { eighth } \\
\text { axis }\end{array}$ & $\begin{array}{l}\text { The activities } \\
\text { obstacles }\end{array}$ \\
\hline $\mathrm{qu}$ & $\begin{array}{l}\text {-The } \\
\text { cients } \\
\text { onnair } \\
\text { isions }\end{array}$ & for & $\begin{array}{l}\text { entific } \\
\text { the } \\
\text { first } \\
\text { of }\end{array}$ & \multicolumn{4}{|c|}{$\begin{array}{l}\text { handicapped persons in the } \\
\text { educational activities) } \\
\text { 1- The truth: The truth of the } \\
\text { internal coherence between the } \\
\text { total of each axis and the grand } \\
\text { total: }\end{array}$} \\
\hline
\end{tabular}

Table (3)

the correlation coefficients between the degree of each axis and the total degree $(\mathrm{N}=11)$

\begin{tabular}{c|l|c|c|c}
\hline \hline Sr. & \multicolumn{1}{|c|}{ The axes } & $\begin{array}{c}\text { Mathematical } \\
\text { mean }\end{array}$ & S.D & $\begin{array}{c}\text { "R" } \\
\text { value }\end{array}$ \\
\hline \hline 1 & The religious activity & 34.18 & 18.56 & 0.99 \\
\hline 2 & The cultural activity & 23.36 & 14.57 & 0.96 \\
\hline 3 & The artistic activity & 17.55 & 10.51 & 0.96 \\
\hline 4 & The sports activity & 23.36 & 13.79 & 0.99 \\
\hline 5 & The social activity & 22.00 & 12.00 & 0.99 \\
\hline 6 & The political activity & 25.55 & 14.78 & 0.98 \\
\hline 7 & $\begin{array}{l}\text { The activity of } \\
\text { psychological qualification }\end{array}$ & 27.64 & 14.61 & 0.95 \\
\hline & The obstacles of execution & 42.64 & 23.10 & 0.94 \\
\hline \hline
\end{tabular}

The table "R" value at level $(0.05=0.576)$. Table (4) shows that the correlation coefficient between the degree of each axis and the grand total of the questionnaire ranged from (0.94: 0.99) and they are

Assiut Journal For Sport Science Arts coefficients with a statistical significance at level (0.05), this in its turn indicates to the truth of the internal coherence of the form.

2- The stability

\section{Table (4) \\ the correlation coefficient between the first application and the second application of the form $(\mathrm{N}=11)$}




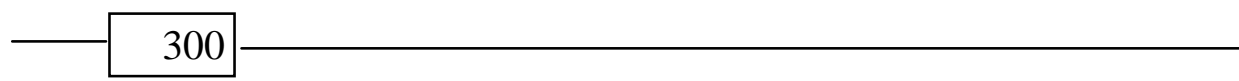

\begin{tabular}{|c|c|c|c|c|c|c|}
\hline \multirow[t]{2}{*}{ Sr. } & \multirow[t]{2}{*}{ The axes } & \multicolumn{2}{|c|}{$\begin{array}{c}\text { The first } \\
\text { application }\end{array}$} & \multicolumn{2}{|c|}{$\begin{array}{l}\text { The second } \\
\text { application }\end{array}$} & \multirow{2}{*}{$\begin{array}{c}\text { The } \\
\text { correlation } \\
\text { coefficient }\end{array}$} \\
\hline & & Average & $\begin{array}{c}\text { The } \\
\text { standard } \\
\text { deviation }\end{array}$ & Average & $\begin{array}{c}\text { The } \\
\text { standard } \\
\text { deviation }\end{array}$ & \\
\hline$\overline{1}$ & $\begin{array}{l}\text { The religious } \\
\text { activity }\end{array}$ & $\overline{34.18}$ & $\overline{18.56}$ & $\overline{34.00}$ & $\overline{15.92}$ & $.9 \mathrm{~V}$ \\
\hline 2 & $\begin{array}{l}\text { The cultural } \\
\text { activity }\end{array}$ & 23.36 & 14.57 & 22.45 & Tr.r. & $\because .99$ \\
\hline 3 & $\begin{array}{l}\text { The artistic } \\
\text { activity }\end{array}$ & 17.55 & 10.51 & 16.82 & 9.79 & .91 \\
\hline 4 & $\begin{array}{l}\text { The sports } \\
\text { activity }\end{array}$ & 23.36 & 13.79 & 23.18 & $M r_{.} \cdot 1$ & .90 \\
\hline 5 & $\begin{array}{l}\text { The social } \\
\text { activity }\end{array}$ & 22.00 & 12.00 & 20.73 & 11.19 & .99 \\
\hline 6 & $\begin{array}{l}\text { The political } \\
\text { activity }\end{array}$ & 25.55 & 14.78 & 25.00 & 13.08 & .99 \\
\hline 7 & $\begin{array}{l}\text { The activity } \\
\text { of } \\
\text { psychological } \\
\text { qualification }\end{array}$ & 27.64 & 14.61 & 26.73 & 12.85 & .97 \\
\hline 8 & $\begin{array}{l}\text { The obstacles } \\
\text { of execution }\end{array}$ & 20.36 & 10.95 & 19.45 & 10.04 & $\cdot .91$ \\
\hline & $\begin{array}{l}\text { The whole } \\
\text { form }\end{array}$ & 299.45 & 160.92 & 292.36 & 143.70 & .99 \\
\hline
\end{tabular}

"R" value at level $0.05=0.576$

Table (4) shows that there is a relationship with a statistical significance between the first application and the second application in all axes of the form about the reality of the participation of the disabled in the educational activities as well as the whole form, since the correlation coefficient ranged from $(0.95$ :

0.99) which in its turn indicates to the stability of the form.

The results of the study:

Presenting and discussing the results of the first questions:

1- What is the reality of participation by the physically handicapped persons in the educational activities at the sports centers and its obstacles?

Table (5)

shows the reality of participation by the physically handicapped persons in the educational activities at the sports centers Assiut Journal For Sport Science Arts 


\begin{tabular}{|c|c|c|c|c|c|}
\hline \multirow[b]{2}{*}{ Sr. } & \multirow[b]{2}{*}{ The axes } & \multicolumn{2}{|c|}{ The whole sample } & \multirow[b]{2}{*}{ The order } & \multirow[b]{2}{*}{ Remarks } \\
\hline & & $\begin{array}{c}\text { The } \\
\text { estimated } \\
\text { degree }\end{array}$ & $\begin{array}{c}\text { The } \\
\text { relative } \\
\text { weight }\end{array}$ & & \\
\hline 1 & $\begin{array}{c}\text { The religious } \\
\text { activity }\end{array}$ & 097 & $0 \% 9.7 \mathrm{~V}$ & The seventh & \\
\hline 2 & $\begin{array}{c}\text { The cultural } \\
\text { activity }\end{array}$ & $\{71$ & $001 . Y Y$ & the fourth & \\
\hline 3 & $\begin{array}{c}\text { The artistic } \\
\text { activity }\end{array}$ & ro. & $\% 0 \cdot \ldots$ & The sixth & \\
\hline 4 & $\begin{array}{c}\text { The sports } \\
\text { activity }\end{array}$ & ราร & $\% 01.07$ & The third & \\
\hline 5 & $\begin{array}{c}\text { The social } \\
\text { activity }\end{array}$ & $r \cdot \Lambda$ & $\% \leqslant \varepsilon . \vee 0$ & The eighth & \\
\hline 6 & $\begin{array}{c}\text { The political } \\
\text { activity }\end{array}$ & $\varepsilon \cdot \varepsilon$ & $\% 0^{0} \cdot \ldots$ & The fifth & \\
\hline 7 & $\begin{array}{l}\text { The activity of } \\
\text { psychological } \\
\text { qualification }\end{array}$ & Or. & $\%$ or... & The second & \\
\hline \multirow[t]{2}{*}{8} & $\begin{array}{l}\text { The obstacles } \\
\text { of execution }\end{array}$ & 117 & $\% 01 . r q$ & The first & \\
\hline & $\begin{array}{l}\text { The whole } \\
\text { form }\end{array}$ & 1919 & $\% \leqslant \Lambda .9 \wedge$ & $\begin{array}{c}\text { Weak } \\
\text { participation }\end{array}$ & \\
\hline
\end{tabular}

\section{Table (5) shows the following:}

- The responses of the whole sample to the axes of the form that relate to the participation by the physically handicapped persons in the educational activities at the sports centers with estimated degree (3919) with an average $(48.98 \%$ )in a weak form.

- $\quad$ The sample's responses from the disabled regarding the obstacles of executing the activities came in the first place with a percentage (58.29\%) with acceptable degree, whereas the sample responses from the disabled regarding their participation in the religious activities came in the seventh place with a percentage $(49.67 \%)$ with a weak degree.

- The sample's responses from the disabled regarding their participation in the cultural activities came in the fourth place with a percentage $(5122 \%)$ with acceptable 
degree, whereas their responses regarding their participation in the artistic activities came in the sixth place with a percentage of $(50 \%)$ with acceptable degree.

- The sample's responses from the disabled regarding their participation in the sports activities came in the third place with a percentage (51.56\%)with acceptable degree, whereas their responses regarding their participation in the social activities came in the eighth place with a percentage of $(44.75 \%)$ with a weak degree.
- $\quad$ The sample's responses from the disabled regarding their participation in the political activities came in the fifth place with a percentage $(50 \%)$ with acceptable degree, whereas their responses regarding their participation in the psychological qualification came in the second place with a percentage of $(52 \%)$ with acceptable degree.

2- The differences between the male and female in their responses to the tripartite scale:

Table (6)

The differences between the male and female in the axes of participation by the physically handicapped persons in the educational activities at the sports centers for caring the disabled and its obstacles $(\mathrm{N}=9,11)$

\begin{tabular}{|c|c|c|c|c|c|c|}
\hline \multirow[t]{2}{*}{ Sr. } & \multirow[t]{2}{*}{ The axes } & \multicolumn{2}{|c|}{ Males $(\mathrm{N}=9)$} & \multicolumn{2}{|c|}{ Females $(\mathrm{N}=11)$} & \multirow{2}{*}{$\begin{array}{c}\text { The } \\
\text { calculated } \\
\text { value of } \\
\text { "T" }\end{array}$} \\
\hline & & Average & $\begin{array}{c}\text { The } \\
\text { standard } \\
\text { deviation }\end{array}$ & Average & $\begin{array}{c}\text { The } \\
\text { standard } \\
\text { deviation }\end{array}$ & \\
\hline 1 & $\begin{array}{l}\text { The religious } \\
\text { activity }\end{array}$ & T1.07 & $\overline{\lambda \wedge . \wedge \Lambda}$ & r^.r & $1 . . \% 0$ & $\cdot V r$ \\
\hline 2 & $\begin{array}{l}\text { The cultural } \\
\text { activity }\end{array}$ & TE.Tr & IT... & rr... & $1 \cdot . r$ & $\because \leqslant V$ \\
\hline 3 & $\begin{array}{l}\text { The artistic } \\
\text { activity }\end{array}$ & $17 . \vee \wedge$ & $\wedge . \wedge$. & 11.99 & $\varepsilon .10$ & $\because \leqslant Y_{-}$ \\
\hline 4 & $\begin{array}{ll}\text { The } & \text { sports } \\
\text { activity } & \end{array}$ & YY.VA & $\checkmark .01$ & Tr.00 & $11.9 \leq$ & $.1 V_{-}$ \\
\hline 5 & $\begin{array}{l}\text { The social } \\
\text { activity }\end{array}$ & $r \cdot . \wedge q$ & $\Lambda . V Y$ & $10 . \leqslant 0$ & $9 . V Y$ & $1 . \mu$. \\
\hline
\end{tabular}

Follow Table (6)

The differences between the male and female in the axes of participation by the physically handicapped persons in the 
educational activities at the sports centers for caring the disabled and its obstacles $(\mathrm{N}=9,11)$

\begin{tabular}{|c|c|c|c|c|c|c|}
\hline \multirow[t]{2}{*}{$\overline{\text { Sr. }}$} & \multirow[t]{2}{*}{ The axes } & \multicolumn{2}{|c|}{ Males $(\mathrm{N}=9)$} & \multicolumn{2}{|c|}{ Females $(\mathrm{N}=11)$} & \multirow{2}{*}{$\begin{array}{c}\text { The } \\
\text { calculated } \\
\text { value of } \\
\text { "T" }\end{array}$} \\
\hline & & Average & $\begin{array}{c}\text { The } \\
\text { standard } \\
\text { deviation }\end{array}$ & Average & $\begin{array}{c}\text { The } \\
\text { standard } \\
\text { deviation }\end{array}$ & \\
\hline 6 & $\begin{array}{l}\text { The political } \\
\text { activity }\end{array}$ & ro. $\leqslant \varepsilon$ & $9 . \leqslant Y$ & $r \cdot .99$ & V.TI & $1 . \leqslant 1$ \\
\hline 7 & $\begin{array}{l}\text { The activity of } \\
\text { psychological } \\
\text { qualification }\end{array}$ & Y^.YY & $1 \cdot . v \cdot$ & $r \leqslant .1 \wedge$ & 11.15 & $\because \wedge r$ \\
\hline \multirow[t]{2}{*}{8} & $\begin{array}{l}\text { The obstacles of } \\
\text { execution }\end{array}$ & $r \leq .$. & $1 \cdot . r q$ & $r V . \leqslant 0$ & $\wedge . \wedge 1$ & $\cdot \wedge l-$ \\
\hline & The whole form & rq9.rT & 07.79 & $r \vee \wedge . \leqslant 0$ & $r \varepsilon .9$ & $1 .+r$ \\
\hline
\end{tabular}

Table value of $(\mathrm{T})$ at level $0.05=2.101$

Table (6) shows the following:

- There are differences with no statistical significance between the male and female in the axes of participation by the physically handicapped persons in the educational activities at the sports centers for caring the disabled and its obstacles since the calculated value of (T) ranged from $(-0.17: 1.41)$ and it is fewer than its table value at level 0.05 , this agrees to the scarcity of putting a media strategy that concerns with making the people aware

with the danger of the problems that relate to the physically handicapped persons, in particular the female, and the necessity of the inclusion process to these categories inside the centers.

Second: presenting and discussing the results of the second question:

- What is the reality of executing the activities included in the sports centers of training the physically handicapped persons? 
Table (7)

the differences between the male and female regarding the reality of executing the educational activities in the real world $(\mathrm{N}=9,11)$

\begin{tabular}{|c|c|c|c|c|c|c|}
\hline \multirow[t]{2}{*}{ Sr. } & \multirow[t]{2}{*}{ The axes } & \multicolumn{2}{|c|}{ Males $(\mathrm{N}=9)$} & \multicolumn{2}{|c|}{$\begin{array}{c}\text { Females }(\mathrm{N}= \\
11)\end{array}$} & \multirow{2}{*}{$\begin{array}{c}\text { The } \\
\text { calculated } \\
\text { value of } \\
\text { "T" }\end{array}$} \\
\hline & & س س & $\tau$ & س س س & $\tau$ & \\
\hline$\overline{1}$ & $\begin{array}{ll}\text { The } & \text { religious } \\
\text { activity } & \\
\end{array}$ & $19 .$. & r.o. & $1 V . \leqslant 0$ & $1 . \varepsilon$ & $1 . \wedge V$ \\
\hline 2 & $\begin{array}{l}\text { The cultural } \\
\text { activity }\end{array}$ & $1 \leq .7 V$ & $\varepsilon . \Gamma$. & $1 \leq .11$ & 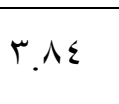 & $\because Y V$ \\
\hline 3 & $\begin{array}{l}\text { The artistic } \\
\text { activity }\end{array}$ & $1 \cdot . r Y$ & ז.7. & 11.00 & $r .1 V$ & $\because \wedge V_{-}$ \\
\hline 4 & The sports activity & $1 T . \varepsilon \varepsilon$ & $\varepsilon . \varepsilon Y$ & 14.91 & $\varepsilon . V$. & . \\
\hline 5 & The social activity & $11.2 \wedge$ & $\varepsilon .+7$ & $11 . \leqslant 0$ & r.V. & $\cdot .9 V_{-}$ \\
\hline 6 & $\begin{array}{l}\text { The political } \\
\text { activity }\end{array}$ & $1 \leq \ldots$ & $\varepsilon . \vee \varepsilon$ & $10 . \leqslant 0$ & $\{.17$ & $\because V \mu_{-}$ \\
\hline 7 & $\begin{array}{l}\text { The activity of } \\
\text { psychological } \\
\text { qualification }\end{array}$ & 10.Y & $\leqslant . \wedge 9$ & $\mid v .91$ & $\varepsilon .1$ & $1 . r 0_{-}$ \\
\hline 8 & The whole form & $1 \% r . \wedge 9$ & rA.rT & $1 \leqslant \cdot . \leqslant 0$ & 19.00 & $\because 0 \cdot-$ \\
\hline
\end{tabular}

Table value of $(\mathrm{T})$ at level $0.05=2.101$

Table (7) shows the following:

- $\quad$ There are differences with no statistical significance between the male and female in the axes of the form regarding the reality of executing the educational activities, since the calculated value of $(\mathrm{T})$ ranged from $(0.01$ :

1.78) and it is fewer than its table value at level 0.05 . This comes in accordance with the social customs and traditions in the Upper Egypt which see that the female's exit for doing sports as a time-waste. 
Table (8)

shows the reality of executing the activities and the extent of participation by the physically handicapped persons in these activities

\begin{tabular}{|c|c|c|c|c|c|c|}
\hline \multirow[t]{2}{*}{ Sr. } & \multirow[t]{2}{*}{ The axes } & \multicolumn{2}{|c|}{$\begin{array}{l}\text { The sample's } \\
\text { responses regarding } \\
\text { the reality of executing } \\
\text { the activities in the } \\
\text { sports centers }\end{array}$} & \multicolumn{2}{|c|}{$\begin{array}{c}\text { The sample's } \\
\text { responses regarding } \\
\text { the participation of the } \\
\text { disabled in the } \\
\text { activities inside the } \\
\text { sports centers }\end{array}$} & \multirow[b]{2}{*}{ remarks } \\
\hline & & $\begin{array}{l}\text { The } \\
\text { relative } \\
\text { weight }\end{array}$ & $\begin{array}{l}\text { The } \\
\text { estimated } \\
\text { degree }\end{array}$ & $\begin{array}{l}\text { The } \\
\text { relative } \\
\text { weight }\end{array}$ & $\begin{array}{l}\text { The } \\
\text { estimated } \\
\text { degree }\end{array}$ & \\
\hline 1 & $\begin{array}{l}\text { The religious } \\
\text { activity }\end{array}$ & 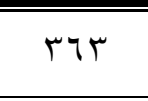 & \% \% & 097 & $\%$ \% & \\
\hline 2 & $\begin{array}{l}\text { The cultural } \\
\text { activity }\end{array}$ & rAN & $\% \wedge \cdot . \cdots$ & $\{71$ & $\% 01 . Y Y$ & \\
\hline 3 & $\begin{array}{l}\text { The artistic } \\
\text { activity }\end{array}$ & Y19 & $\%$ \%^.Y। & ro. & $\% 0 \cdot \ldots$ & \\
\hline 4 & $\begin{array}{l}\text { The sports } \\
\text { activity }\end{array}$ & $T V \varepsilon$ & $\% \vee 7.11$ & $\leqslant 7 \varepsilon$ & $\% 01.07$ & \\
\hline 5 & $\begin{array}{l}\text { The social } \\
\text { activity }\end{array}$ & YOS & $\% \vee \vee . \wedge$ & $r \cdot \Lambda$ & $\% \leq \varepsilon . \vee 0$ & \\
\hline 6 & $\begin{array}{l}\text { The political } \\
\text { activity }\end{array}$ & rTr & $\% \wedge r . Y r$ & $\varepsilon \cdot \varepsilon$ & $\% 0 \cdot \ldots$ & \\
\hline 7 & $\begin{array}{l}\text { The activity } \\
\text { of } \\
\text { psychological } \\
\text { qualification }\end{array}$ & צ ז & $\% \wedge r .0$. & Or. & $\%$ or... & \\
\hline 8 & $\begin{array}{l}\text { The obstacles } \\
\text { of execution }\end{array}$ & --- & ---- & 117 & $\% 01 . Y 9$ & \\
\hline & The whole form & 1990 & $\% \vee 9.19$ & $\mu$ & $\% \leqslant \Lambda .9 \wedge$ & \\
\hline
\end{tabular}

Table (8) shows that:

- The responses of the whole sample to the axes of the form that relate to the participation of the physically handicapped persons in the educational activities in the sports centers came with an estimated degree (3919)with a percents of (48.98\%)in a weak degree, whereas the responses of the whole sample to the axes of the form that relate to the execution of the educational activities for the disabled in the sports centers came with an estimated degree (3919) with a 
percentage (79.29) with high degree.

- The responses of the sample from the disabled regarding the obstacles of executing the activities came in the first place with a percentage $(58.29 \%)$ with acceptable degree.

The results of the study:

1- The results that relate to the reality of executing the educational activities in the sports centers and the participation of the physically handicapped persons:

The results of the field study revealed some results, the most important of them are:

- $\quad$ There are differences with no statistical significance between the male and female in the axes of the form regarding the reality of executing the educational activities, since the calculated value of $(\mathrm{T})$ ranged from $(0.01$ : 1.78) and it is fewer than its table value at level (0.05).

- There are differences with no statistical significance between the male and female in the axes of participation by the physically handicapped persons in the educational activities at the sports centers for caring the disabled and its obstacles since the calculated value of (T) ranged from (-0.17: 1.41) and it is fewer than its table value at level 0.05 .

- $\quad$ There are shortcomings in participation of the disabled in the education activities (the religious- the cultural- the artistic- the sports- the socialthe political- the psychological qualification) inside the sports centers, whereas the executing of the educational activities inside the sports centers for the physically handicapped persons came with strong degree. Hare are the results:

- The responses of the whole sample to the axes of the form that relate to the participation by the physically handicapped persons in the educational activities at the sports centers with estimated degree (3919) with an average $(48.98 \%)$ in a weak form, whereas the responses of the whole sample to the axes of the form that relate to the execution of the educational activities for the disabled in the sports centers came with an estimated degree 3919 with a percentage (79.29) with high degree.

- The responses of the sample from the disabled

Assiut Journal For Sport Science Arts 
regarding the obstacles of executing the activities came in the first place with a percentage $(58.29 \%)$ with acceptable degree.

Second the proposed vision for activating the role of the sports centers for the physically handicapped persons

The philosophy of the proposed vision

The philosophy of this proposal emerges from the reality of the level of the educational activities and the caring provide to the disabled inside the sports centers for the physically handicapped persons and is in march with the social contemporary variables and the direct and indirect due effects and consequences, in the same time, this proposal aims to improve and to deepen the improvement of the caring provided to this category.

The vision basics and motives:

- The efforts exerted for caring the disabled are distinguished by its protective and curing nature and there are divided into two integrated and correlated parts: The first part is represented in the services and potentialities provided by Assiut Journal For Sport Science Arts the country for the disabled with the purpose of helping them to develop their human abilities.

- The second part is represented in directing the abilities of the disabled and their creative abilities and investing their free-time in the positive contribution for building the society.

\section{The goals of the vision:}

- This vision aims to prepare the physically handicapped persons in the moral, sports, religious, political, artistic and social aspects for giving the opportunity for the physically handicapped persons to reach the good citizenship.

- $\quad$ Achieving the integrated growth for the member in all aspects to the extent he will be able to use his abilities and skills.

- Providing the opportunity for examining and testing a lot of the recent educational events because of their flexibility and the freedom of participation.

- Providing the opportunity to those who didn't learn through opening the classes for eliminating the 
illiteracy and developing the educational values acquired from the school education.

The characteristics of the proposed vision are derived from a lot of the findings as follow:

1- The amended physical education that relates to the caring in the light of the social contemporary variables is the real income for upgrading and developing the level of the education provided for the physically handicapped persons.

2- $\quad$ The caring required by the sports centers for the disabled needs to be restructured regarding the material and abstract potentialities. It also needs to a guiding program regarding the way of dealing with the physically handicapped persons and providing the services and educational activities they need.

1- The protection from the disability:

- The arrangements of requalification which are represented in the physical requalification, the educational requalification and the

- economic requalification.
Second: Encouraging the non-governmental

\section{organizations:}

1- $\quad$ The necessity of making the necessary arrangements for improving the access to the disabled. The vision also motivates to reinforce the participation, inclusion and the increasing respect for the independency and dignity of the disabled.

2- Forming the policies, standards and legislations that don't consider the needs of the disabled, for example the policy of the comprehensive education and giving low priority for the requalification process.

Through providing the activities of the sports centers for the physically handicapped persons, we must a lot of basics including:

- The variety of the activities for achieving the integrated development for the individual, since the modern education looks at the activities as the basic pillar in the educational process.

- $\quad$ Providing

the

opportunity for the positive and negative participation 
according to the desire and tendency of each member.

- Each activity must perform its role in the different educational fields including the religious, cultural, artistic, sports, social, political and psychological aspects.

\section{The recommendations:}

- Reconsidering the policies, legislations and services provided to the disabled.

- The investment in defined programs and sorting the services provided for the disabled.

A) The recommendations relate to the laws and legislations.

- Developing the current laws and resolutions in the way that is proper to the social and world changes in dealing with these special categories.

- Passing the laws that bind those who care these institutions to declare their specialized programs for qualifying these categories.

b) The recommendations relate to the media and its institutions:

Putting media strategy that concerns with forming a popular awareness regarding the danger of the problem and the necessity of incorporating these categories and creating media programs that relate to the disabled children to help them to understand the reality of their disability and to discover their ability as well as training them to use their abilities positively.

\section{The references}

\section{First: Arabic references}

1- Osama Riyadh: Nahed Ahmed Abdel Raheem: The measurement and the physical qualification for the disabledThe house of Arab ThoughtCairo 2001.

2- The central body for mobilization and counting: the final results for the census and the population conditions- the total population of the republic 2008- page 370.

3 - The general authority for inquiry- Assuit 2008.

4- Hassan Shehata: The school activity, its concept, functions and the fields of applying it- Cairo- the Egyptian House 1997- page 22. 5- HelmyAhmed Ibrahim and Layla Farahat: The sports education and recreation for the disabled- Cairo- The House of Arab Thought 1998 page 37.

6- Khalil

Wadeea

Shakour: Disabled but great 
individuals- The Arab House for Sciences- the first edition 1995- page 35.

7- Randa

Refa't

Mohammed Mahfouz: The educational, social and psychological caring for the children with special needs in the light of the social contemporary variablesdoctorate dissertation- Assuit University- faculty of education 2006.

8- Samy Mohammed

Melhem: The curriculum of research in the education and psychology- Oman 2006 page 307.

9- A'ssem Moahmmed

Morsy: Putting a strategy for the activities of the sports recreation in the sports centers for the disabled in the Arab Republic of Egypt- doctorate dissertation- Alexandria University- faculty of physical education for girls 2008 .

10- Abeer Farouq Hanna

Sa'ad: Preparing the teacher of the special education in Egypta future vision- unpublished
Master dissertation- institute if the educational studies and researches- Cairo University 1996.

11- Medhat Mohammed Abu Al Naser: The disability and the disabled- modern vision- The Arabic group for training- Cairo 2009- page 27.

\section{The foreign references}

1- -Deborah Marks;: Disability controversial debates and Psychosocial, Routdge, London, 1999, p. 98

2- vailable at: http://www.sis.gov .eg/Ar/Last Page. Aspx Category_ ID $=1798$ - Accessed at: (4/12/2013).

\section{3- Hisayo Katsui:} mainstreaming disability issues in Japanese and finish Development policies and practices working paper- the institute of development studies, Helsinki University, 2008, p. 19.

4- Saunders accountability, Journal article, Opinion paper, 2010 . 